\title{
Goalball as an effective means of physical improvement for blind and visually impaired players
}

\author{
Józef Krzak', Marzena Ślężyńska², Jan Ślężyński² \\ ${ }^{1}$ Medical University of Lublin, Poland \\ ${ }^{2}$ Academy of Physical Education, Katowice, Poland
}

Krzak J, Ślężyńska M, Ślężyński J. Goalball as an effective means of physical improvement for blind and visually impaired players. Med Og Nauk Zdr. 2015; 21(4): 383-387. doi: 10.5604/20834543.1186910

\section{Abstract}

The study was performed between 2002-2006 among players aged 16-18 practicing goalball in order to investigate the beneficial effects of the game on physical fitness, spatial orientation and sound localization in people with visual impairment. Substantial progress in physical fitness of all motor skills in goalball players was confirmed. Tests for visual orientation and sound localization also demonstrated significant improvement in the time needed to perform the given trial. Goalball is worthy of becoming widespread as it produces evident personal and social benefits. The great attraction of sport games practiced by disabled persons became the impulse for searching for a physical game available for blind and visually impaired people. The bells embedded in the rubber ball made this possible and created a new concept of the game and has made it popular worldwide.

\section{Key words}

goalball, physical fitness, people with visual impairment

\section{INTRODUCTION}

Goalball is a sport played at the Paralympics by blind and visually impaired players. The playing court dimensions are $18 \times 9 \mathrm{~m}$, with the shorter sides of the court considered the goal lines. The height of the goalpost is $1.3 \mathrm{~m}$. The team consists of three players and three reserve players. The court is marked out with string held in place by $5 \mathrm{~cm}$ wide adhesive tape. The lines should be easily detectable by the players' hands and feet. The object of the game is to throw a ball weighing $1.25 \mathrm{~kg}$ and $76 \mathrm{~cm}$ in diameter with metal bells inside, and with 8 holes of $1 \mathrm{~cm}$ in diameter for better audibility. Thus, silence during game is vital. One team must roll the ball past the goal line to score. In order to maintain an equal advantage, all team members must wear opaque goggles and sticking plaster on their eyes during the game $[1,2,3]$.

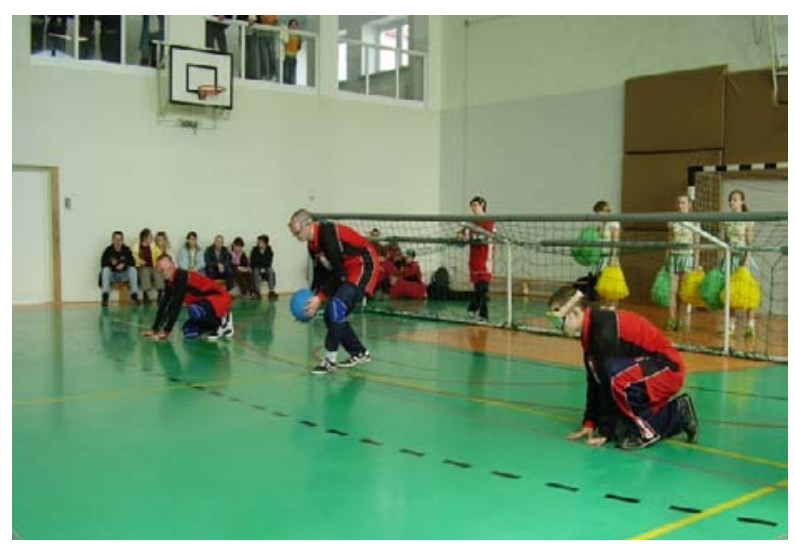

Figure 1. Goalball game

Adres do korespondencji: Marzena Ślężyńska, ul. B.Chrobrego 25/130, 40881 Katowice

E-mail: marzena.slezynska@wp.pl

Nadesłano: 19 maja 2014; zaakceptowano do druku: 3 listopada 2015

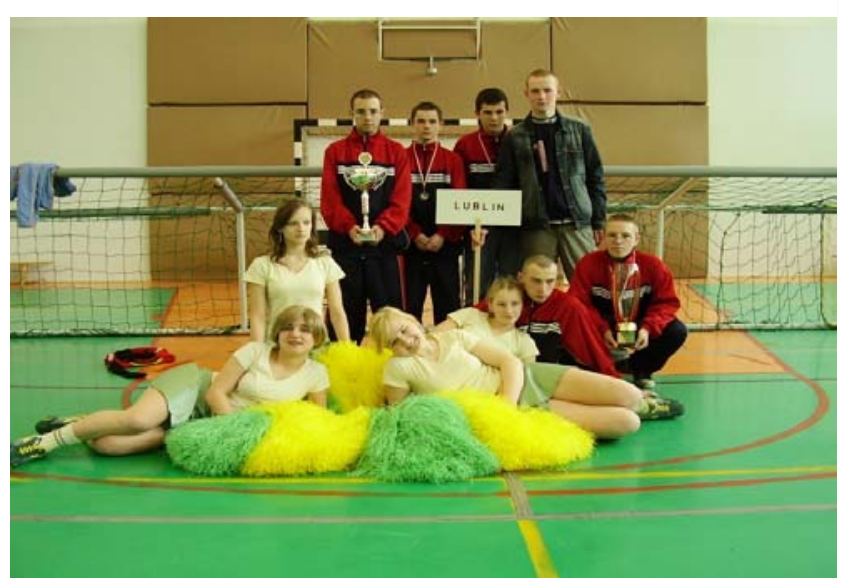

Figure 2. Goalball players of of the 'Start' Sports Association in Lublin

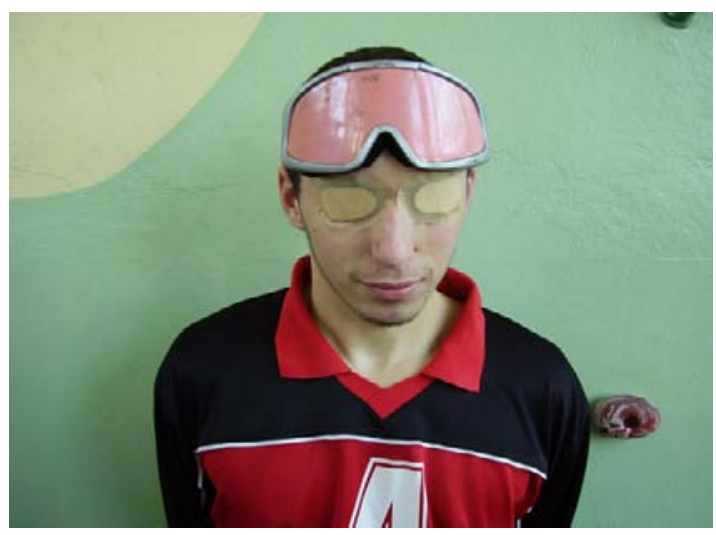

Figure 3. All players must wear opaque goggles and sticking plaster on their eyes 


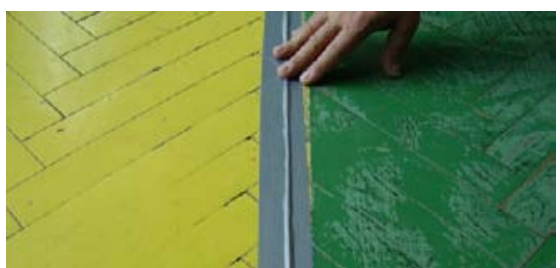

Figure 4. Court is marked out with string held in place by $5 \mathrm{~cm}$ wide adhesive tape which can be easily detected by players' hands and feet

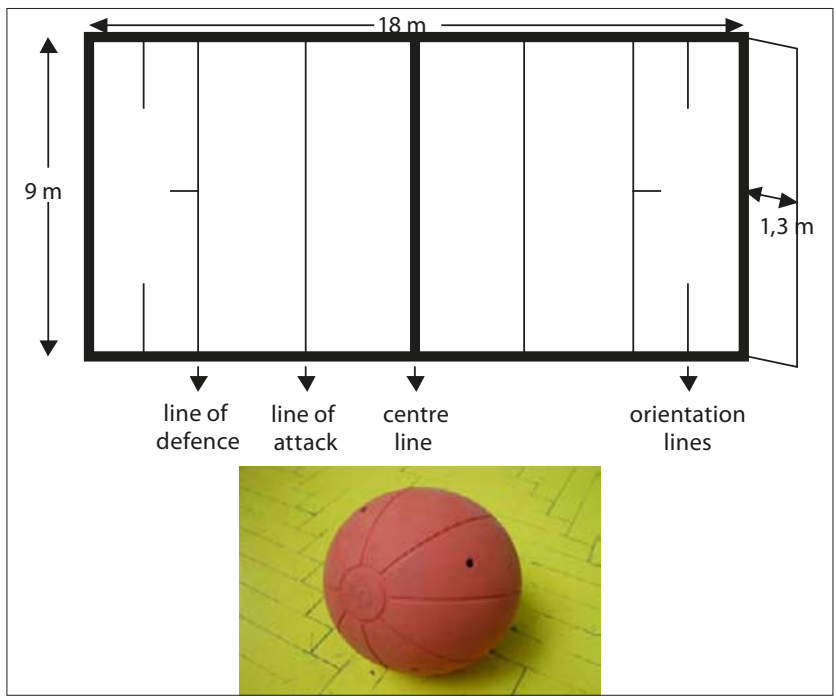

Figure 5. Playing court dimensions are $18 \times 9 \mathrm{~m}$ (on the left), shorter sides are considered goal lines, height of goalpost is $1.3 \mathrm{~m}$. Inside the ball (on the right) there are metal bells producing sounds

A goal attack throw is allowed within the distance of $6 \mathrm{~m}$ from own goal, and defence is allowed within a distance of $3 \mathrm{~m}$ from own goal. The game consists of two 10-minute halves and one 5-minute halftime. The game is very dynamic and spectacular, requiring absolute spatial orientation, sound localization and good physical fitness [4].

A team of referees watch over the game: main referee, auxiliary referee, two goal line referees, one referee measuring time and one recorder. A foul results in a penalty throw. There are 2 kinds of penalty situations, committed either by a player or by a team. During a penalty throw for a personal foul, the goal defender is the player who committed the foul. The player can make only 2 successive throws. The next throw by the same player is considered a foul and a penalty throw is awarded to the opposite team.

The team has 10 seconds to throw the ball after receiving it. After any pauses during the game, the players change, and other reasons for stopping a game result in 10 seconds being added to the passing time. After resumption of the game, the team have the time remaining from 10 seconds, counted from the first ball contact. If the team do not throw the ball within 10 seconds, a penalty throw is awarded. No tutor, trainer or reserve player can instruct the team in other time out of the game rules. Otherwise, it is considered to be a team foul and is penalised with a penalty throw [4].

\section{MATERIALS AND METHOD}

The study was performed conducted between 2002-2006 in goalball players aged $16-18$ in order to investigate the beneficial effects of the game on physical fitness, spatial orientation, and sound localization in people with visual impairment. Initially, 15 goalball players from the Educational Centre for the Visually Impaired in Lublin (9 persons) and from a complex of Vocational Schools (6 persons) participated in the research. There were 12 visually impaired players (class B2) and 3 blind players (class B1). In 2005, the research group consisted of 11 players ( 9 visually impaired and 2 blind), and in December 2006 there were 10 players (8 visually impaired and 2 blind) as 5 persons gave up practicing goalball. Control group constituted 10 students from the Educational Centre and Medical Vocational School in Lublin (8 visually impaired and 2 blind), who participated in physical education activities [5] but had never practiced goalball.

It was hypothesised that blind and visually impaired goalball players would demonstrate better general and specific physical fitness compared to the control group.

The research programme in 2002-2005 included:

- general physical fitness evaluation with the Zuchora Physical Fitness Index (velocity, jump, flexibility, handgrip, abdominal muscle strength) [6], with the modification of a blind player running with a guide holding a sash;

- sound localization evaluation with the use of balls [2];

- spatial orientation evaluation on the goalball court [2].

In 2006, the Larson International Test of Physical Efficiency was used to measure motor fitness and special physical fitness (sound localization and spatial orientation) in the sports group and control group.

Fitness tests were performed in the 'Start' athletics stadium and sports hall in Lublin. Every trial was preceded by a warm-up. The subjects wore sports clothes (T-shirt, shorts, tracksuit, sport shoes). Pull ups and bends forward were performed barefoot.

The sound localization test began with a starting position in the centre of the goal line. Balls joined by a rope were hung on the left and right goalposts, and were operated by a researcher; a third goalball was placed in the centre of the third meter line. The researcher moved the ball 5 times and the player had to locate it by taking a defensive position towards the moving ball. Task performance time and its correctness were evaluated. The exercise was performed in opaque goggles. A false location of the ball resulted in a penalty second being awarded.

Lines marking the playing court and goals were used to test spatial orientation. A blindfolded player stood in the middle of the goal touching the crossbar with his fingers. After the 'start' signal he tried to find the third meter line as quickly as possible and return to the goal, touch the crossbar. Next, he looked for the sixth meter line and again touched the crossbar. The resulting time showed the level of orientation.

Statistic method. Means $(\bar{x})$, standard deviations (s) and medians $(\mathrm{Me})$ were calculated. Suitable tests were used in statistical analysis [7]. Kolmogorow-Smirnow Test was used to check for normal data distribution. Based on this, test Mann-Whitney Test was chosen for groups comparisons (U). For comparison of the physical fitness results in the years 2001-2005, Friedman ANOVA Test was used, verified by $\chi^{2}$ test, as it also did not meet the normality condition or equality of variance. Thoroughness of measurements was verified using Kendall coefficient of concordance $\left(\mathrm{V}_{\mathrm{K}}\right)$. Arm strength was measured using $\chi^{2}$ test, as it is a qualitative attribute (non-measurable). 


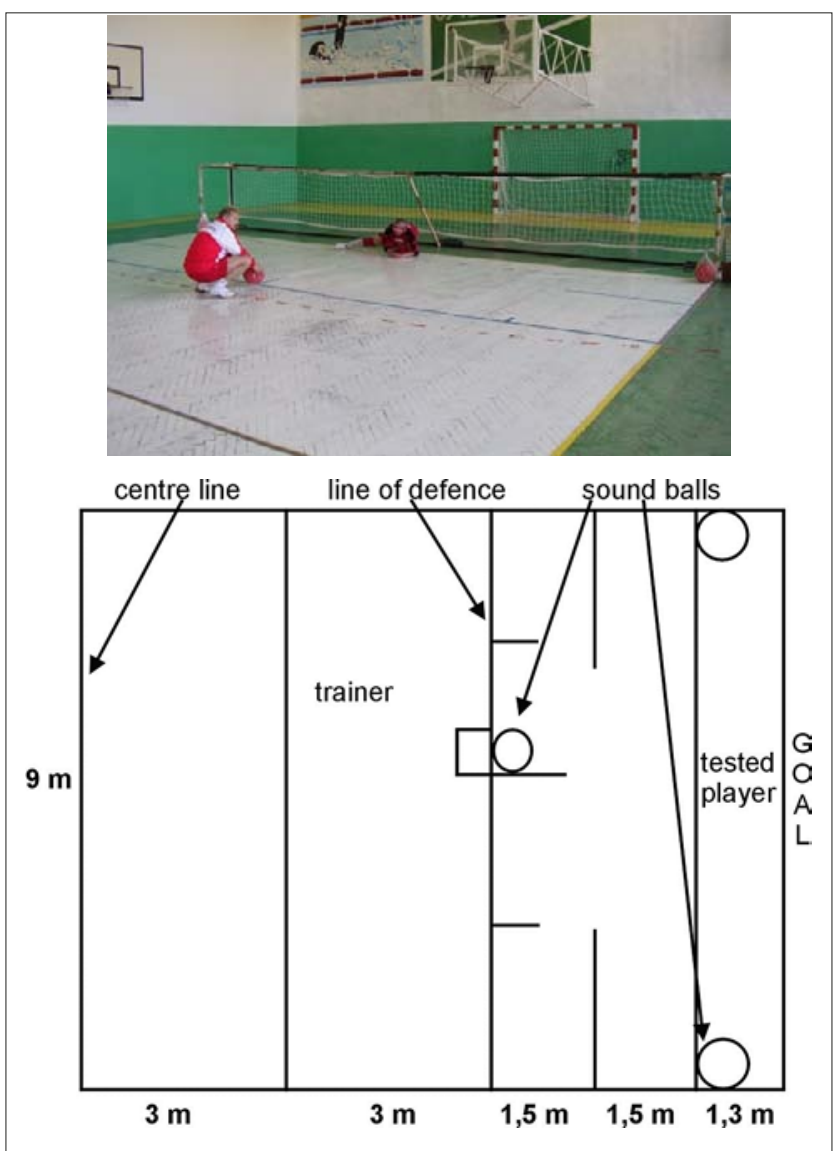

Figure 6. Sound localization test. Player takes a starting position in the centre of the goal line. Balls joined with a string were hung to the left and the right goalpost, and operated by a researcher; a third ball is placed in the centre of the third meter line. The researcher moves the ball 5 times and the player locates it, taking a defensive position towards the moving ball. Task performance time and its correctness are evaluated. Exercise performed in opaque goggles. False location of the ball resulted in adding a penalty second.

General and special physical fitness. In 2002-2005, general physical fitness was improved in all kinds of motor skills, and especially in running strength and abdominal muscle strength (Tab. 1). Total scores obtained by players demonstrated systematic progress in physical fitness (Tab. 2). Running-in-place time during 10 seconds demonstrated significant speed progress in the subsequent years $\left(\chi^{2}=33.0\right.$; $\mathrm{p}<0.001)$. Minimal running speed in running-in-place was noted in 2002 (21.09 claps) and maximal in 2005 (31.27 claps). It must be noted that in 2002, a half of the players performed the speed of less than 20 clasps and in 2005 less than 31 clasps.

Kendall coefficient of concordance (1.0) demonstrated very strong results correlation in the subsequent years. Significant progress was also noticed in the strength test (standing long jump) ( $\left.\chi^{2}=25.52 ; \mathrm{p}<0.001\right)$. Length of the jump was increased, on average, from $5.91 \mathrm{~m}$ in 2002 to $7.55 \mathrm{~m}$ in 2005. Kendall indicator $(\mathrm{VK}=0.77)$ also confirmed high homogeneity of the test results. Trained players also showed significant improvement in the flexibility test (forward bends) $\left(\chi^{2}=29.69 ; \mathrm{p}<0.001\right)$, as the arithmetic means $(\bar{x})$ increased from 2.09 in 2002 to 4.0 in $2005(\mathrm{VK}=0.90)$.

Goalball also strongly influenced players' strength $\left(\chi^{2}=\right.$ 31.70; $\mathrm{p}<0.001)$. In 2002, tested players ran, on average, $745.46 \mathrm{~m}$ and after 4 years $2272.73 \mathrm{~m}$. The median significantly increased from 800 in the beginning, to 2,000 in the last year $(\mathrm{VK}=0.96)$. Goalball also influenced significantly the

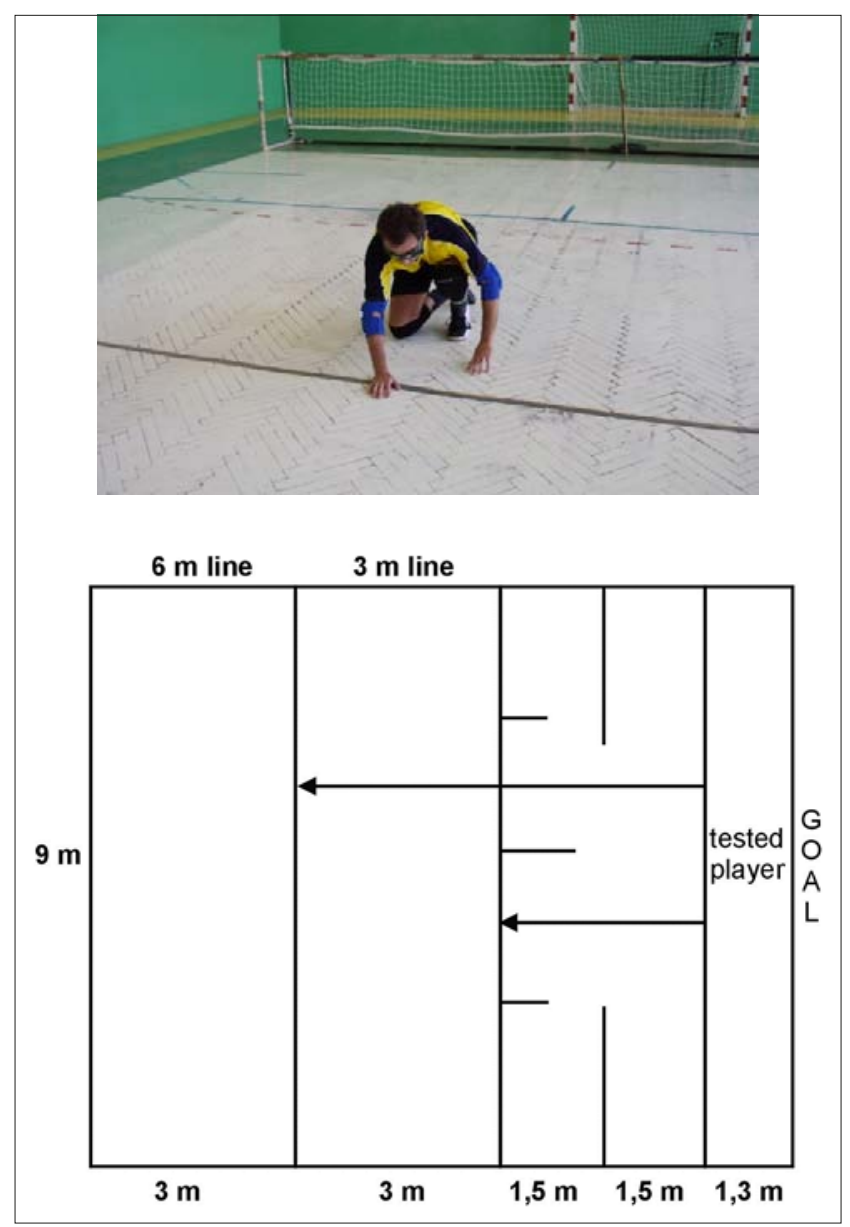

Figure 7. Spatial orientation test. Blindfolded player stands in the middle of the goal touching the crossbar with his fingers. After the 'start' signal he quickly tries to find the third meter line, return to the goal and touch the crossbar. Next, he looks for the sixth meter line and again returns to touch the crossbar. The time is measured with 0.1 second accuracy.

performed time of forward bends, proving the increased strength of abdominal muscles. There were significant differences between results obtained in the subsequent years of practicing goalball $\left(\chi^{2}=32.50 ; \mathrm{p}<0.001\right)$. Also, the performed time of scissor exercises improved during the 4 years, from $36 \mathrm{sec}$ to $89.64 \mathrm{sec}$, and the median (Me) increased 4 times $(\mathrm{VK}=0.98)$. A significant upper limbs muscle growth in goalball players was also noted $\left(\chi^{2}=74.11 ; \mathrm{p}<0.001\right)$.

Global point evaluation [6] showed significant improvement in general physical fitness of the goalball players. In the first year of practicing this sport, the average was 11.45 points and after 4 years 23 points $\left(\chi^{2}=33.00 ; \mathrm{p}<0.001\right)$ (Tab. 1,2$)$.

Spatial orientation and sound localization tests showed significant improvement in the time needed for correct test performance (Tab. 3). Special fitness results showed significant reduction in the time needed to locate the sound in goalball players. This was demonstrated both in arithmetic means $(\bar{x})$ and in medians $(\mathrm{Me})$. The average decreased from $23.62 \mathrm{sec}$. to $13.42 \mathrm{sec}$. and median from $22.4 \mathrm{sec}$. to $13.8 \mathrm{sec} .\left(\chi^{2}=33.00\right.$; $\mathrm{p}<0.001)$. Time of spatial orientation was significantly shorter, from an average of $32.38 \mathrm{sec}$. in 2002 to an average of $12.03 \mathrm{sec}$. in 2005. A significant median decrease was also shown during the 4 years. In 2002, a half of the players achieved a spatial orientation test time below $33.2 \mathrm{sec}$, and in 2005 below 12.1 $\mathrm{sec}$. The researches confirmed that spatial orientation was significantly improved in goalball players $\left(\chi^{2}=33.00 ; \mathrm{p}<0.001\right)$. 
Table 1. General physical fitness of players in 2002-2005, estimated by the Zuchora Physical Fitness Index

\begin{tabular}{|c|c|c|c|c|}
\hline Years & Min-max & & $\mathrm{s}$ & $\mathrm{Me}$ \\
\hline \multicolumn{5}{|c|}{ speed test (clasps under knees) } \\
\hline 2002 & $16-26$ & 21.09 & 3.21 & 20 \\
\hline 2003 & $18-32$ & 25.27 & 4.15 & 25 \\
\hline 2004 & 23-39 & 29.46 & 4.82 & 29 \\
\hline 2005 & $24-40$ & 31.27 & 4.74 & 31 \\
\hline \multicolumn{5}{|c|}{ jump test (standing long jump) } \\
\hline 2002 & $5-7$ & 5.91 & 0.54 & 6 \\
\hline 2003 & $6-8$ & 6.82 & 0.60 & 7 \\
\hline 2004 & $6-9$ & 7.18 & 1.08 & 7 \\
\hline 2005 & 7-9 & 7.55 & 0.69 & 7 \\
\hline \multicolumn{5}{|c|}{ flexibility test (forward bends) } \\
\hline 2002 & $2-3$ & 2.09 & 0.30 & 2 \\
\hline 2003 & $2-4$ & 2.91 & 0.54 & 3 \\
\hline 2004 & $3-4$ & 3.55 & 0.52 & 4 \\
\hline 2005 & $3-5$ & 4.00 & 0.45 & 4 \\
\hline \multicolumn{5}{|c|}{ strength test (distance running) } \\
\hline 2002 & $400-1,000$ & 745.46 & 220.74 & 800 \\
\hline 2003 & $800-2,000$ & 1372.73 & 479.77 & 1,500 \\
\hline 2004 & $1,000-3,000$ & 2000.00 & 707.11 & 2,000 \\
\hline 2005 & $1,500-3,000$ & 2272.73 & 564.08 & 2,000 \\
\hline \multicolumn{5}{|c|}{ abdominal muscle test (scissor exercise) } \\
\hline 2002 & $20-60$ & 36.00 & 12.57 & 35 \\
\hline 2003 & $20-80$ & 43.55 & 16.11 & 41 \\
\hline 2004 & $25-120$ & 68.55 & 25.72 & 65 \\
\hline 2005 & $40-140$ & 89.64 & 29.14 & 91 \\
\hline
\end{tabular}

Table 2. Total number of points obtained by goalball players in Zuchora Physical Fitness Index in 2002-2005

\begin{tabular}{lcccc}
\hline Years & Min-max & $\bar{x}$ & $s$ & Me \\
\hline 2002 & $8-13$ & 11.45 & 1.69 & 12.0 \\
\hline 2003 & $12-19$ & 16.46 & 2.38 & 17.0 \\
\hline 2004 & $14-26$ & 20.46 & 3.96 & 20.0 \\
\hline 2005 & $18-27$ & 23.00 & 2.90 & 23.0 \\
\hline
\end{tabular}

Table 3. Special physical fitness of goalball players in 2002-2005, evaluated by sound localization and spatial orientation tests

\begin{tabular}{lllll}
\hline Years & Min-max & $\bar{x}$ & $\mathrm{~s}$ & Me \\
\hline \multicolumn{5}{c}{ sound localization test (s) } \\
\hline 2002 & $18.1-33.1$ & 23.62 & 3.99 & 22.4 \\
\hline 2003 & $14.3-21.3$ & 17.57 & 1.85 & 17.3 \\
\hline 2004 & $11.3-19.1$ & 15.15 & 2.00 & 15.1 \\
\hline 2005 & $11.0-15.3$ & 13.42 & 1.35 & 13.8 \\
\hline \multicolumn{5}{c}{ spatial orientation test (s) } \\
\hline 2002 & $25.2-41.2$ & 32.38 & 4.25 & 33.2 \\
\hline 2003 & $16.1-27.0$ & 20.41 & 3.48 & 18.9 \\
\hline 2004 & $11.5-17.4$ & 14.71 & 1.84 & 14.2 \\
\hline 2005 & $9.3-13.8$ & 12.03 & 1.19 & 12 \\
\hline
\end{tabular}

Table 4. General fitness of goalball sport group and control group, evaluated with Larson International Test of Physical Efficiency

\begin{tabular}{|c|c|c|c|c|}
\hline Group & Min-max & $\bar{x}$ & s & $\mathrm{Me}$ \\
\hline \multicolumn{5}{|c|}{$50 \mathrm{~m}$ running (sec.) } \\
\hline Sport group & $7.0-8.2$ & 7.77 & 0.43 & 7.95 \\
\hline Control group & $7.8-11.5$ & 8.87 & 1.06 & 8.65 \\
\hline \multicolumn{5}{|c|}{$U=11,0 ; p<0,01$} \\
\hline \multicolumn{5}{|c|}{ standing long jump (cm) } \\
\hline Sport group & $190-240$ & 215.7 & 13.76 & 215 \\
\hline Control group & $120-210$ & 170.7 & 22.52 & 175 \\
\hline \multicolumn{5}{|c|}{$U=2,5 ; p<0,001$} \\
\hline \multicolumn{5}{|c|}{1000 m running (sec.) } \\
\hline Sport group & $179-216$ & 198.5 & 10.77 & 198 \\
\hline Control group & $205-320$ & 243.6 & 32.27 & 233 \\
\hline \multicolumn{5}{|c|}{$\mathrm{U}=4.0 ; \mathrm{p}<0.001$} \\
\hline \multicolumn{5}{|c|}{ upper limb muscle strength (kG) } \\
\hline Sport group & $40-70$ & 52.7 & 9.64 & 55 \\
\hline Control group & $19-45$ & 33.1 & 9.36 & 32.5 \\
\hline \multicolumn{5}{|c|}{$U=7.0 ; p<0.01$} \\
\hline \multicolumn{5}{|c|}{ pull-up exercise (number) } \\
\hline Sport group & $1-9$ & 4.1 & 2.6 & 3.5 \\
\hline Control group & $0-4$ & 1.6 & 1.17 & 1 \\
\hline \multicolumn{5}{|c|}{$U=17.5 ; p<0.05$} \\
\hline \multicolumn{5}{|c|}{ swing running $4 \times 10 \mathrm{~m}$ (sec.) } \\
\hline Sport group & $9.5-14$ & 10.45 & 1.30 & 10.1 \\
\hline Control group & $12.5-20.3$ & 4.20 & 2.29 & 13.5 \\
\hline \multicolumn{5}{|c|}{$U=6.0 ; p<0.001$} \\
\hline \multicolumn{5}{|c|}{ sit-ups from lying position (number) } \\
\hline Sport group & $26-37$ & 29.6 & 3.24 & 29 \\
\hline Control group & $12-27$ & 22.8 & 4.52 & 24 \\
\hline \multicolumn{5}{|c|}{$U=4.5 ; p<0.001$} \\
\hline \multicolumn{5}{|c|}{ body bends $(\mathrm{cm})$} \\
\hline Sport group & $0-8$ & 3.7 & 2.16 & 4 \\
\hline Control group & $-10-2$ & 3.3 & 4.03 & -3 \\
\hline \multicolumn{5}{|c|}{$U=4.5 ; p<0.001$} \\
\hline
\end{tabular}

General and special physical fitness in goalball sport group and control group. General physical fitness evaluated with the Larson International Test of Physical Efficiency [8] showed significant improvements in all kinds of motor skills in the goalball group compared to control group. Significant time and points differences were demonstrated in $50 \mathrm{~m}$ running and swing running $4 \times 10 \mathrm{~m}$ (Tab. 4). The total number of points of the goalball group was significantly higher compared to control group, which confirms the better general physical fitness of goalball players. Goalball players also had better time in $50 \mathrm{~m}$ running $(7.77 \mathrm{sec}$.) than the control group $(8.87 \mathrm{sec}$.). Standing long jump in players was also significantly higher and confirmed with arithmetic mean $(\bar{x}=215.7 \mathrm{~cm})$, and with median $(\mathrm{Me}=215 \mathrm{~cm})$; differences were $45 \mathrm{~cm}$ and $40 \mathrm{~cm}$.

A similar observation was made in the $1,000 \mathrm{~m}$ running where the goalball players ran faster $(\bar{x}=198.5 \mathrm{sec}$.) than the control group $(\bar{x}=243.6 \mathrm{sec}$.$) . Upper limb muscles strength$ was also significantly higher $(\bar{x}=52.7 \mathrm{kG})$ than in the control group $(\bar{x}=33.1 \mathrm{kG})$. Goalball players also achieved better 
results in pull-ups - average number 4.1 , while in the control group it was only 1.6. Significant differences were observed in swing running $4 \times 10 \mathrm{~m}$. The sport group ran faster, on average $(10.45 \mathrm{sec}$.), than the control group (14.2 sec.). The goalball group was much better in sit-ups from a lying position (29.6 sit-ups) than the control group (22.8 sit-ups). Significant difference were shown in forward bends: the sport group achieved an average of $3.7 \mathrm{~cm}$ and median $4.0 \mathrm{~cm}$, and the control group $-3.3 \mathrm{~cm}$ and $3.0 \mathrm{~cm}$, respectively.

Other authors have also measured motor fitness, but by using different fitness tests. Significant differences were noted in sit and reach tests, flamingo balance test, grip strength of dominant hand, and vertical jump; the results were higher in each trial between the goalball group and control group [9]. The same results were noted using the Brockport Physical Fitness Test Battery. Physical fitness of visually impaired goalball players was higher than in the sedentary group [10].

Special physical fitness tests. such as the spatial orientation and sound localization tests. also showed better results in thegoalball group compared to the control group $(\mathrm{p}<0.001)$ (Tab. 5). The time needed for spatial orientation test performance and sound localization test performance was significantly shorter (average $13.28 \mathrm{sec}$.. median 13 . sec.) than in the control group (average $15.83 \mathrm{sec}$. median $15.8 \mathrm{sec}$.)

Table 5. Special physical fitness of sport group and control group evaluated with sound localization and spatial orientation tests

\begin{tabular}{lcccc}
\hline Group & Min-max & $\bar{x}$ & s & Me \\
\hline \multicolumn{5}{c}{ sound localization test } \\
\hline Sport group & $9.1-12.9$ & 13.28 & 1.04 & 13.5 \\
\hline
\end{tabular}

\section{CONCLUSIONS}

The results of this study allow the following conclusions to be drawn:

1. In 2002-2005. all goalball players made significant progress in general physical fitness of all motor abilities. and specially in running strength and abdominal muscles strength.
2. In 2002-2005. special physical fitness tests - spatial orientation and sound localization - demonstrated significant improvement in the time needed for correct task performance in goalball players.

3. Significant benefits in goalball group compared to control group were showed in all kinds of motor abilities. especially significant time and points differences were noted for $50 \mathrm{~m}$ running and swing running $4 \times 10 \mathrm{~m}$.

4. Total number of points on the Larson International Test of Physical Efficiency was significantly higher for the goalball group. which demonstrated better general physical fitness of the players compared to their non-playing peers.

5. Special fitness tests. such as the spatial orientation and sound localization tests. showed significantly greater benefits in the goalball group.

6. The study confirmed that goalball brings evident personal and social benefits. The examples of the blind and visually impaired players show that this sport helps to deal with the effects of visual impairment.

\section{REFERENCES}

1. Bolach E. Kształtowanie orientacji przestrzennej u niedowidzących w sportowych grach zespołowych. Fizjoterapia 1994; 1: 25-29.

2. Bolach E, Pełka P. Ocena sprawności fizycznej inwalidów narządu wzroku uprawiających sportowe gry zespołowe (torball. goalball). Post Rehab. 1995; 3: 71-79.

3. Bolach E. Sportowe gry zespołowe w usprawnianiu niewidomych i niedowidzących. AWF. Wrocław 1999.

4. Krzak J, Prażmo R. Goalball. PZSN „Start”. Warszawa 2005.

5. Gawlik K, Zwierzchowska A. Wychowanie fizyczne niewidomych i słabo widzących. AWF. Katowice 2004.

6.Zuchora K. Indeks Sprawności Fizycznej. AWF. Warszawa 1982.

7. Stanisz A. Przystępny kurs statystyki w oparciu o program „Statistica PL". Kraków 1998.

8. Pilicz S, Przewęda R, Dobosz J, Nowacka-Dobosz S. Punktacja sprawności fizycznej młodzieży polskiej według Międzynarodowego Testu Sprawności Fizycznej. AWF. Warszawa 2004.

9. Colak T, Mamaç B, Aydin M, Mariç B, Özbek A. Physical fitness levels of blind and visually impaired goalball team players. Isokinet Exerc Sci. 2004; 12: 247-252.

10. Karakaya IC, Aki E, Ergun N. Physical fitness of visually impaired adolescent goalball players. 2009; 108 (1): 129-36.

\title{
Golball skutecznym środkiem usprawniania niewidomych i słabo widzących
}

\author{
I Streszczenie \\ Wstęp. Goalball jest grą paralimpijską uprawianą przez niewidomych i słabo widzących. Gra odbywa się na boisku \\ o wymiarach $18 \times 9 \mathrm{~m}$. \\ Materiał i metoda. W celu stwierdzenia jak goalballl oddziałuje na sprawność fizyczną, orientacje przestrzenną i lokalizację \\ źródła dźwięku osób z dysfunkcją narządu wzroku w latach 2002-2006 wykonano badania zawodników w wieku 16-18 lat \\ uprawiających tę dyscyplinę sportu. \\ Wyniki. Badania potwierdziły znaczną progresję sprawności fizycznej zawodników trenujących piłkę bramkową (goalball) \\ we wszystkich zdolnościach motorycznych. Testy orientacji przestrzennej i lokalizacji źródła dźwięku również wykazały \\ znaczącą poprawę czasu potrzebnego na właściwe wykonanie danej próby. \\ Wnioski. Goalball jest godny upowszechnienia, gdyż przynosi ewidentne korzyści osobnicze i społeczne oraz łagodzi \\ skutki niepełnosprawności wzrokowej.
}

\section{- Słowa kluczowe}

goalball, aktywność fizyczna, niewidomi 